REMOVAL OF CHLORINATED AND NON-CHLORINATED ALKANES IN A

TRICKLE-BED BIOFILTER

$$
\text { CONF- } 980632-
$$

K. Thomas Klasson, Brian H. Davison, John W. Barton, and Jennifer E. Jacobs

Chemical Technology Division

Oak Ridge National Laboratory ${ }^{1}$

Oak Ridge, Tennessee 37831-6044

Publication \& Presentation

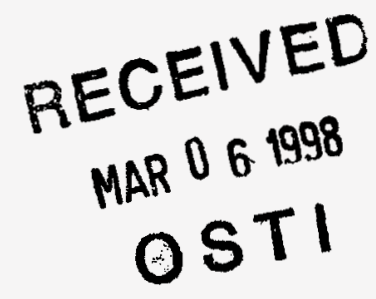

Air \& Waste Management Association's

$91^{\text {st }}$ Annual Meeting \& Exhibition

June 14-19, 1998

San Diego, California

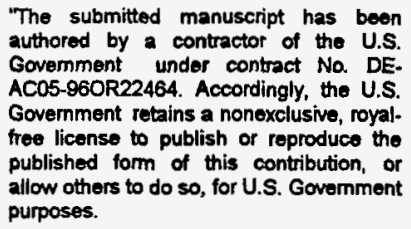

purposes.

DISTRIBUTION OF THIS DOCUMENT IS UNLMMTED

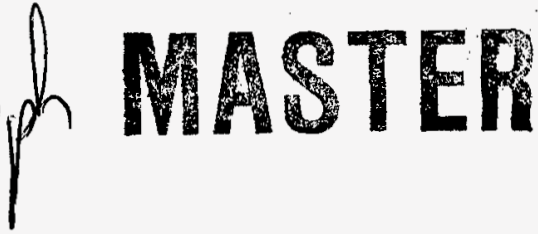

\footnotetext{
${ }^{1}$ Managed by Lockheed Martin Energy Research Corp. for the U.S. Department of Energy under contract DE-AC05-96OR22464
} 


\section{DISCLAIMER}

This report was prepared as an account of work sponsored by an agency of the United States Government. Neither the United States Government nor any agency thereof, nor any of their employees, makes any warranty, express or implied, or assumes any legal liability or responsibility for the accuracy, completeness, or usefulness of any information, apparatus, product, or process disclosed, or represents that its use would not infringe privately owned rights. Reference herein to any specific commercial product, process, or service by trade name, trademark, manufacturer, or otherwise does not necessarily constitute or imply its endorsement, recommendation, or favoring by the United States Government or any agency thereof. The views and opinions of authors expressed herein do not necessarily state or reflect those of the United States Government or.any agency thereof. 


\title{
Removal of Chlorinated and Non-Chlorinated Alkanes in a Trickle-Bed Biofilter
}

\section{8-A437}

\author{
K. Thomas Klasson, Brian H. Davison, John W. Barton, and Jennifer E. Jacobs \\ Oak Ridge National Laboratory (managed by Lockheed Martin Energy Research Corp. for the \\ U.S. Department of Energy under contract DE-AC05-96OR22464), Oak Ridge, TN 37831-6044
}

\begin{abstract}
Increasing restrictions in emissions from a variety of industrial settings demand low cost removal of dilute contaminants in air. Many of these contaminants such as volatile organic components (VOCs) and sulfur compounds are biodegradable and can be removed from air streams via biofiltration. The simplest form of biofiltration consists of compost-based systems. More advanced systems designed for unique contaminants are biofilters with bioactive structured packing operating in trickle-bed mode. These advanced systems rely on a microbial consortium capable of degrading the contaminants of concern and the consortium usually is isolated or enriched from a more complex microbial mixture.
\end{abstract}

This paper describes the use of a trickle-bed reactor seeded with a microbial consortium enriched from a methanotrophic culture. The microbial consortium has been found to degrade chlorinated alkanes as the sole carbon source. Degradation rates of alkane mixtures are presented for the trickle-bed as well as results from batch cultures experiments designed to study degradation of various chlorinated and non-chlorinated VOCs.

\section{INTRODUCTION}

Increasing restrictions in emissions from a variety of industrial settings demand low cost removal of dilute contaminants in air. Many of these contaminants, such as volatile organic components (VOCs) and sulfur compounds, are biodegradable and can be removed from air streams via biofiltration. ${ }^{1}$ The simplest form of biofiltration consists of compost- or soil-based systems. More advanced designs for unique contaminants are biofilters with a bioactive, structured packing operating in a trickle-bed mode. ${ }^{2}$ These advanced systems rely on microbial consortia capable of degrading the contaminants of concern and the cultures are usually isolated or enriched from a more complex microbial mixture.

\section{METHODS}

The mixed culture used in the study has been described elsewhere; ${ }^{3,4}$ it can be characterized as an aerobic alkanotrophic culture enriched from a methanotrophic consortium; the improved culture has lost its ability to consume methane. The culture was maintained on salts medium (Medium 1, Table 1). The gas phase typically consisted of different alkanes or chlorinated alkanes in air (details in figure captions). Glass vials (various volumes) used for the batch studies were sealed with butyl-rubber stoppers and aluminum crimp-seals. Sterile controls were prepared in an identical fashion before sterilization at $121^{\circ} \mathrm{C}$ for $30 \mathrm{~min}$. Blank controls had viable microorganisms but no gaseous carbon source. The vials were shaken in a rotary shaker 
incubator at about $125 \mathrm{rpm}$ at $30^{\circ} \mathrm{C}$. The trickle-bed reactor was $50 \mathrm{~cm}$ long and had an internal diameter of $5 \mathrm{~cm}$. It contained a structured polyethylene packing (Koch Industries) to maximize surface area, minimize pressure drop, and enhance mass transfer. Gas and liquid were fed to the top of the reactor. A schematic of the system may be seen in Figure 1.

Gas samples ( 0.1 to $0.3 \mathrm{~mL}$ ) were injected directly into a Hewlett-Packard gas chromatograph (Model 5890) equipped with a flame ionization detector and an Alltech AT-624 capillary column $(60 \mathrm{~m} \times 0.53 \mathrm{~mm} \mathrm{ID})$. For gas phase oxygen, a thermocouple detector and a Hewlett-Packard HPPLOT (Molecular Sieve 5A) capillary column $(30 \mathrm{~m} \times 0.53 \mathrm{~mm} \mathrm{ID})$ were utilized. Cell density was measured at $600 \mathrm{~nm}$ on a Milton Roy Spectronic 21D spectrometer and compared to a previously created calibration curve. Chloride concentration was measured using a Orion chloride-sensitive electrode.

\section{RESULTS}

The consumption of straight and branched alkanes simultaneously is not new. Babu and Brown reported that a strain of Nocardia paraffinicum consumed propane and isobutane in a gas mixture. ${ }^{5}$ In their studies, they noted that either substrate was consumed by itself, regardless of prior substrate preference; e.g., propane-grown cells readily consumed isobutane. However, when the gases were added in mixtures, significant inhibition was noted. Isobutane and propane was also degraded in a soil bioreactor by Kampbell et al. ${ }^{6}$ Togna and Singh noted that isopentane was consumed by a mixed culture as a sole carbon source in a trickle-bed study. ${ }^{7}$ Numerous other publications have reported microbial n-alkane consumption as well. ${ }^{8,9,10,11}$

In Figure 2, the simultaneous consumption of $\mathrm{C}_{2}-\mathrm{C}_{5}$ alkanes by the culture is displayed. As is noted, methane is not consumed even after prolonged exposure once all other gases were depleted. Pentane and butane were consumed at almost identical rates; propane and ethane consumption was slower. The lack of methane consumption is not new. Takahashi et al. isolated and identified Pseudomonas butanovora as a bacterium capable of utilizing C2-C9 n-alkanes as sole carbon source (the medium contained $0.1 \mathrm{~g} / \mathrm{L}$ yeast extract). ${ }^{12}$ The organism would not grow on methane. Patel et al. isolated 16 new strains of bacteria capable of growth on $\mathrm{C}_{2}-\mathrm{C}_{4}$ alkanes but none could consume methane. ${ }^{11}$ Perry, on the other hand, reported that the bacterial strain JOB5 was capable of growth on C1-C8 alkanes. ${ }^{8}$ Interestingly enough, the capability of consuming $\mathrm{C} 1-\mathrm{C} 3$ alkanes depended on the growth history of the culture; e.g., cells grown on short chain alkanes could consume longer chain alkanes, but the reverse was not true. Brisbane and Ladd also noted simultaneous conversion of methane and other alkanes. ${ }^{13}$ They speculated that enriched microbial cultures from soil contained at least two types of organisms; one that consumed methane and co-consumed ethane, another that consumed propane.

To study the release of chloride via the degradation of chlorinated organics and also to elucidate overall reaction sequence, a set of experiments was conducted by adding different amounts of 1chloropentane as the sole carbon source to otherwise identical microcosms. The cell growth on chloropentane is shown in Figure 3. As is noted in the figure, cell growth was inhibited at chloropentane levels of $41 \mu \mathrm{mol}$. Also note the lack of growth in the absence of chloropentane. At the completion of the experiment, the microcosms were sampled for residual chloropentane (qualitative) and oxygen (quantitative); chloride and $\mathrm{pH}$ were also measured. The results are displayed in Figures 4, 5, and 6. 
To interpret the results, we speculate that there are two predominant reactions for chloropentane conversion:

1. Cell growth: $\mathrm{C}_{5} \mathrm{H}_{11} \mathrm{Cl}+2.5 \mathrm{O}_{2}=>5 \mathrm{CH}_{2} \mathrm{O}+\mathrm{HCl}$

2. Carbon dioxide production: $\mathrm{C}_{5} \mathrm{H}_{11} \mathrm{Cl}+7.5 \mathrm{O}_{2} \Rightarrow 5 \mathrm{CO}_{2}+\mathrm{HCl}+5 \mathrm{H}_{2} \mathrm{O}$

where $\mathrm{CH}_{2} \mathrm{O}$ refers to the simplified molecular structure of cells. Based on the results presented in Figures 4 to 6 , the following overall reaction can be derived.

$\mathrm{C}_{5} \mathrm{H}_{11} \mathrm{Cl}+4.5 \mathrm{O}_{2} \Rightarrow 3 \mathrm{CH}_{2} \mathrm{O}+2 \mathrm{CO}_{2}+\mathrm{HCl}+2 \mathrm{H}_{2} \mathrm{O}$

indicating that $60 \%$ of available carbon was incorporated into cell mass.

The performance of the consortium may be compared with Janssen et al. who describes the organism Xanthobacter autotrophicus $\mathrm{GJ} 10$ as being an organism capable of growth on 1chlorpropane; however, this bacterium lacks capability of growth on pentane or hexane. ${ }^{14}$ The culture in our consortium grow on both these substrates. The proposed degradative pathway for $X$. autotrophicus goes through the alcohol, aldehyde, and carboxylic acid. Another organism, Ancylobacter aquaticus, has been described by van den Vijngaard. ${ }^{15}$ This organism grows on 1,2dichlorethane (as does $X$. autotrophicus) but cannot support growth on longer-chain chloroalkanes. The current consortium may reveal other than these organisms when subjected to rigorous isolation protocol (ongoing).

The conversion of straight and branched alkanes in a trickle-bed rector is shown in Figure 7. This experiment was conducted with the same culture previously described. It is clear that the conversion was more efficient at $30^{\circ} \mathrm{C}$ than at $15^{\circ} \mathrm{C}$. Further information on the column performance has been published elsewhere. ${ }^{16}$ Future column experiments will test the degradation of chloropentane.

\section{REFERENCES}

1. Leson, G.; Winer, A.M. J. Air Waste Mgmt. Assoc. 1991, 41, 1045-1054.

2. Togna, A.P.; Singh, M. Environ. Prog. 1994, 13, 94-97.

3. Davison, B.H.; Thompson, J.E. Biotechnol. Lett. 1993, 15, 633-636.

4. Davison, B.H.; Thompson, J.E. Appl. Biochem. Biotechnol. 1994, 45/46, 917-923.

5. Babu, J.P.; Brown, L R. Appl. Environ. Microbiol. 1984, 48, 260-264.

6. Kampbell, D.H.; Wilson, J.T.; Read, H.W.; Stockdale, T.T. JAPCA 1987, 37, 1236-1240.

7. Togna, A.P.; Singh, M., "A Comparative Study of Biofilter and Biotrickling Filter Performance for Isopentane Removal, "Proceedings of the $87^{\text {th }}$ Annual Air \& Waste Management Association Meeting \& Exhibition, Cincinnati, Ohio, June 19-24, 1994.

8. Perry, J.J. Antonie van Leeuwenhoek 1968, 34, 27-36.

9. Perry, J.J. Adv. Appl. Microbiol. 1980, 26, 89-115.

10. Johnson, M.J. Science 1967, 155, 1515-1519.

11. Patel, R.N.; Hou, C.T.; Laskin, A.; Felix, A.; Derelanko, P. J. Appl. Biochem. 1983, 5, 107120. 
12. Takahashi, J.; Ichikawa, Y.; Sagae, H.; Komura, I.; Kanou, H.; Yamada, K. Agric. Bio. Chem. 1980, 44, 1835-1840.

13. Brisbane, P.G.; Ladd J.N. J. Gen. Appl. Microbiol. 1968, 14, 447-450.

14. Janssen, D.B.; Scheper, A.; Dijkhuizen, L.; Witholt, B. Appl. Environ. Microbiol. 1985, 49, 673-677.

15. van den Wijngaard, A.J.; van der Kamp, K.W.H.J.; van der Ploeg, J.; Pries, F.; Kazemier, B.; Janssen, D.B. Appl. Environ. Microbiol. 1992, 58, 976-983.

16. Barton, J.W.; Klasson, K.T.; Koran Jr., L.J.; Davison, B.H. Biotechnol. Prog. 1997, 13, 814 821. 
Table 1. Media compositions used in experiments.

\begin{tabular}{|c|c|c|}
\hline Component & $\begin{array}{c}\text { Medium } 1 \\
\text { (mg/L) }\end{array}$ & $\begin{array}{c}\text { Medium } 2 \\
\text { (mg/L) }\end{array}$ \\
\hline $\mathrm{Ca}\left(\mathrm{NO}_{3}\right)_{2} \cdot 4 \mathrm{H}_{2} \mathrm{O}$ & & 85 \\
\hline $\mathrm{CaCl}_{2}$ & 200 & \\
\hline $\mathrm{CoCl}_{2} \cdot 6 \mathrm{H}_{2} \mathrm{O}$ & & 0.2 \\
\hline $\mathrm{CoCl}_{2} \cdot \mathrm{H}_{2} \mathrm{O}$ & 0.01 & \\
\hline $\mathrm{CuCl}_{2} \cdot \mathrm{H}_{2} \mathrm{O}$ & & 0.01 \\
\hline $\mathrm{CuSO}_{4} \cdot 5 \mathrm{H}_{2} \mathrm{O}$ & 0.05 & \\
\hline $\mathrm{FeCl}_{2} \cdot 4 \mathrm{H}_{2} \mathrm{O}$ & & 1.5 \\
\hline $\mathrm{FeCl}_{3}$ & 27 & \\
\hline $\mathrm{H}_{3} \mathrm{BO}_{4}$ & & 0.3 \\
\hline $\mathrm{K}_{2} \mathrm{HPO}_{4}$ & 560 & 1500 \\
\hline $\mathrm{KH}_{2} \mathrm{PO}_{4}$ & 440 & 1200 \\
\hline $\mathrm{KNO}_{3}$ & 1000 & 500 \\
\hline $\mathrm{MgSO}_{4} \cdot 7 \mathrm{H}_{2} \mathrm{O}$ & 1000 & 500 \\
\hline $\mathrm{MnCl}_{2} \cdot 4 \mathrm{H}_{2} \mathrm{O}$ & . & 0.03 \\
\hline $\mathrm{MnSO}_{4} \cdot \mathrm{H}_{2} \mathrm{O}$ & 0.01 & \\
\hline $\mathrm{Na}_{2} \mathrm{MoO}_{4} \cdot 2 \mathrm{H}_{2} \mathrm{O}$ & & 0.03 \\
\hline $\mathrm{NaSeO}_{3}$ & . & 0.01 \\
\hline $\mathrm{NH}_{4} \mathrm{Cl}$ & 100 & \\
\hline$\left(\mathrm{NH}_{4}\right)_{2} \mathrm{SO}_{4}$ & & 1250 \\
\hline $\mathrm{NiCl}_{2} \cdot 6 \mathrm{H}_{2} \mathrm{O}$ & & 0.02 \\
\hline $\mathrm{Zn}\left(\mathrm{NO}_{3}\right) \cdot 6 \mathrm{H}_{2} \mathrm{O}$ & 0.07 & \\
\hline $\mathrm{ZnSO}_{4} \cdot 7 \mathrm{H}_{2} \mathrm{O}$ & & 0.1 \\
\hline
\end{tabular}


Figure 1. Schematic of trickle-bed reactor used for continuous flow studies. Experiments were conducted with Medium 1 (Table 1). Inlet gas feed consisted of $0.5 \%$ n-pentane and isobutane in air.

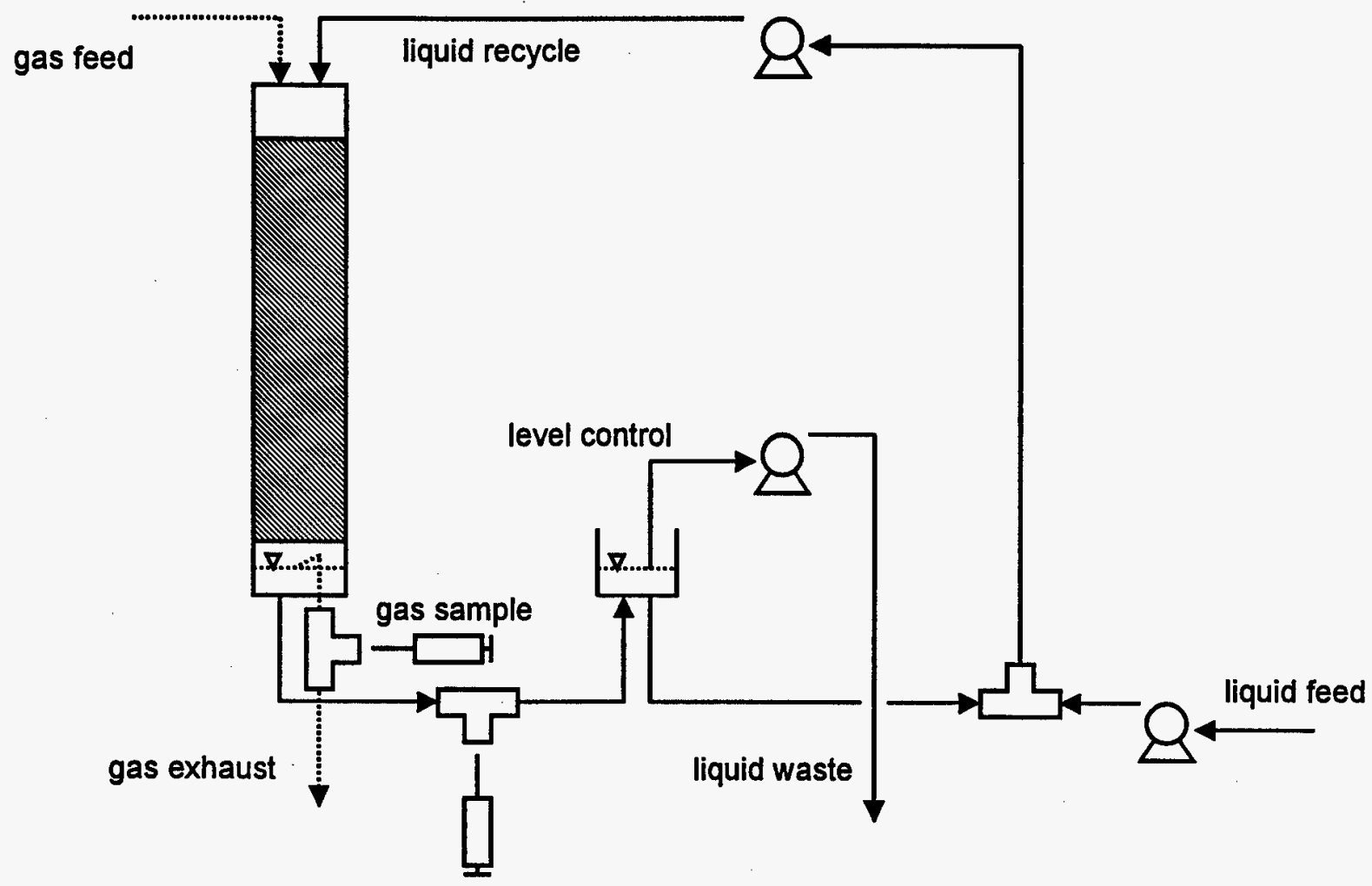

liquid sample 
Figure 2. Consumption of $\mathrm{C}_{1}-\mathrm{C}_{5}$ alkanes by the mixed culture. These studies were conducted in $157-\mathrm{mL}$ serum bottles with a liquid volume of $50 \mathrm{~mL}$ (Medium 1, Table 1). The initial concentration of each gas was approximately $0.85 \%$ in air.

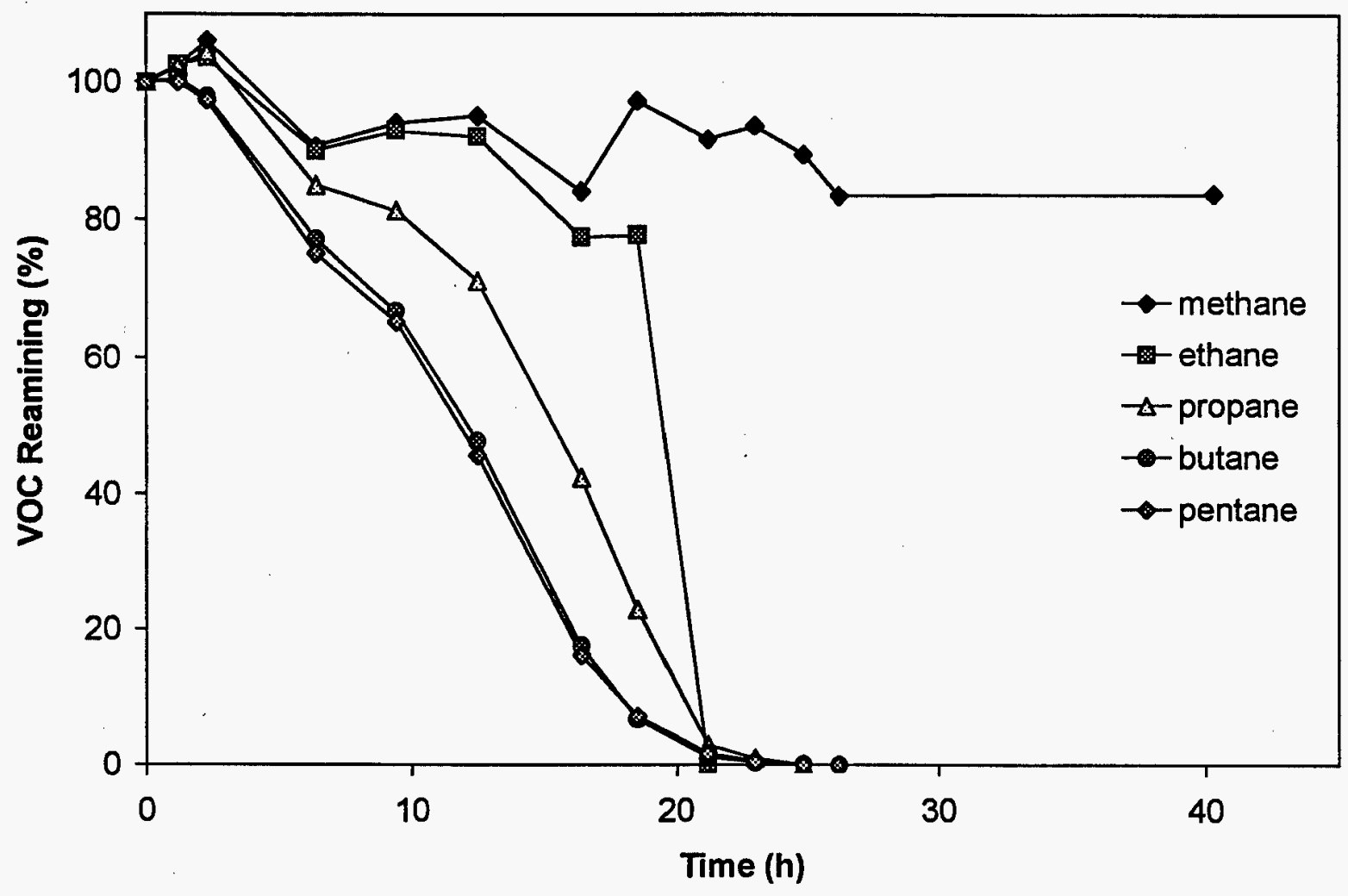


Figure 3. Growth of cell culture on various amounts of chloropentane. These studies were conducted in 26-mL serum test tubes with a liquid volume of $5.5 \mathrm{~mL}$ (Medium 2, Table 1). Various amounts of chloropentane were added to each microcosm.

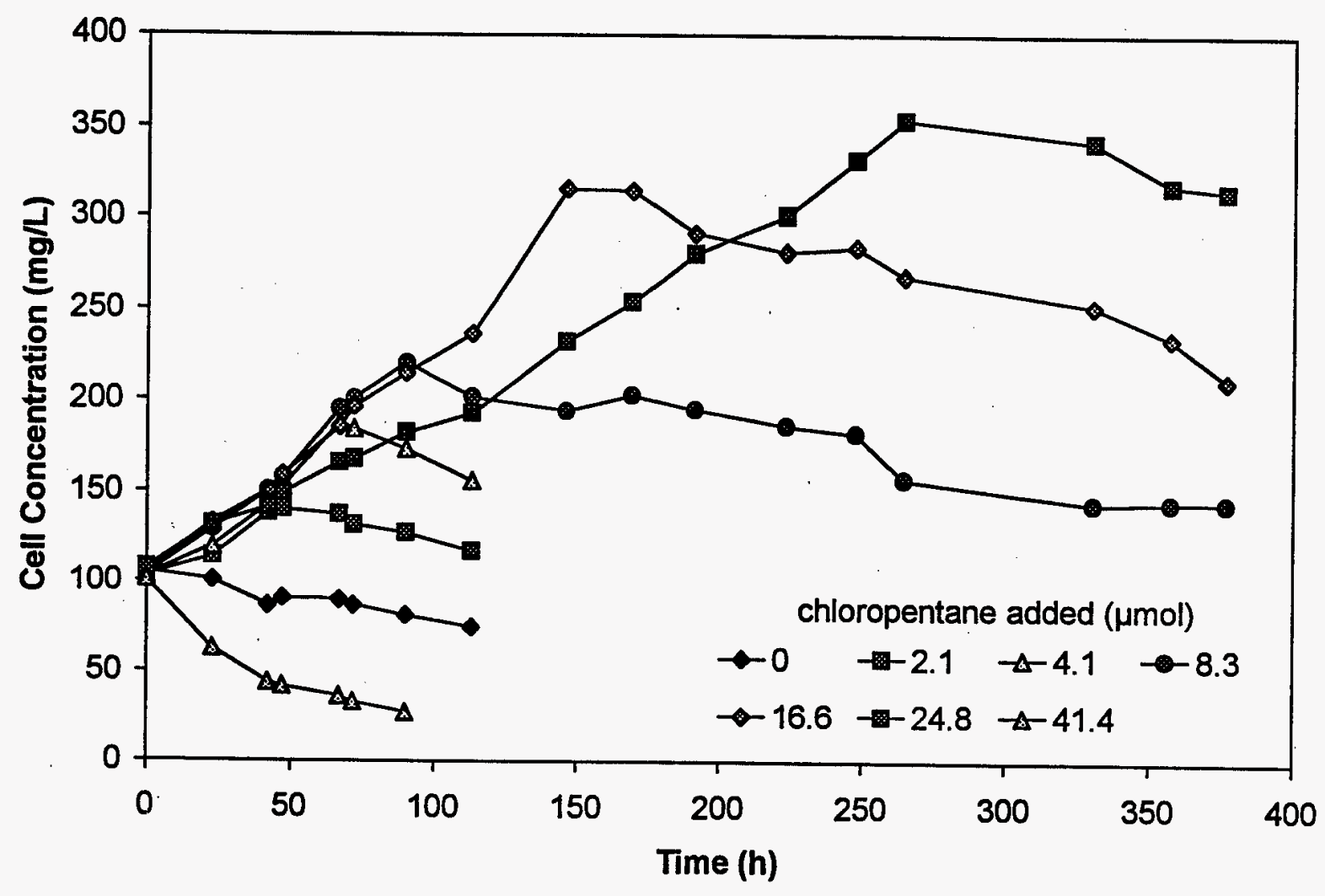


Figure 4. Cell mass produced in experiment set described in Figure 3 caption.

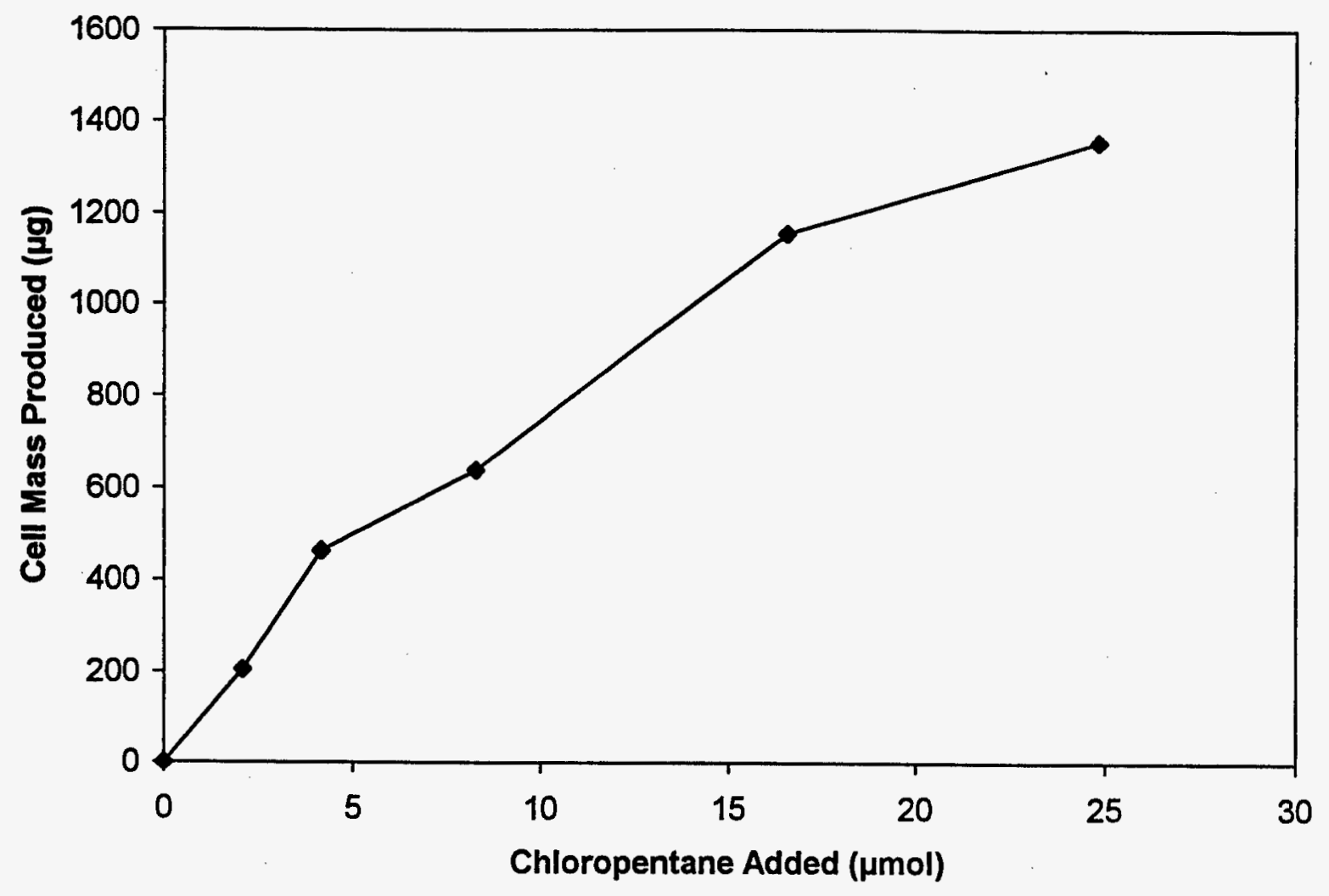


Figure 5. Chloride release in experiment set described in Figure 3 caption.

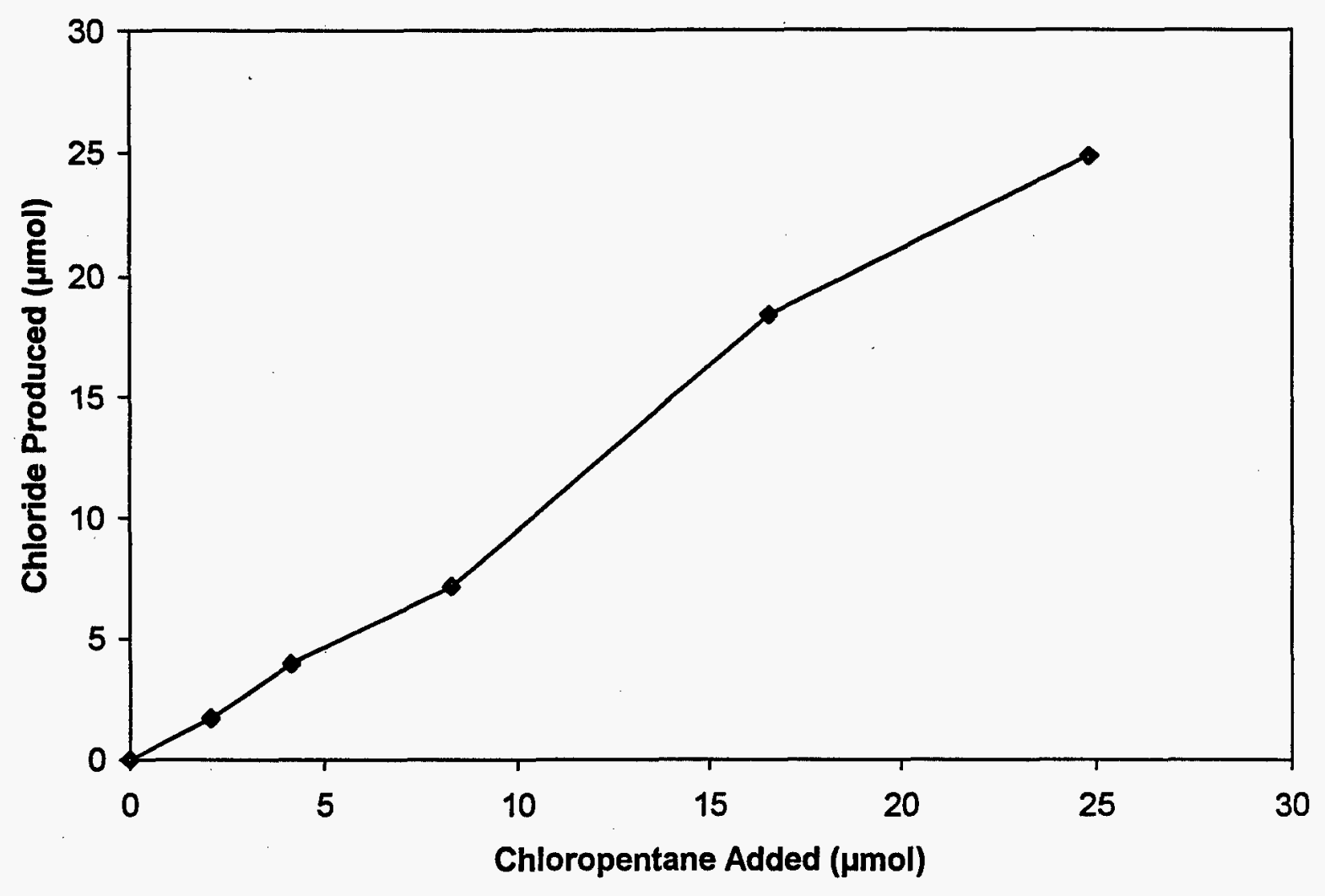


Figure 6. Residual oxygen in experiment set described in Figure 3 caption.

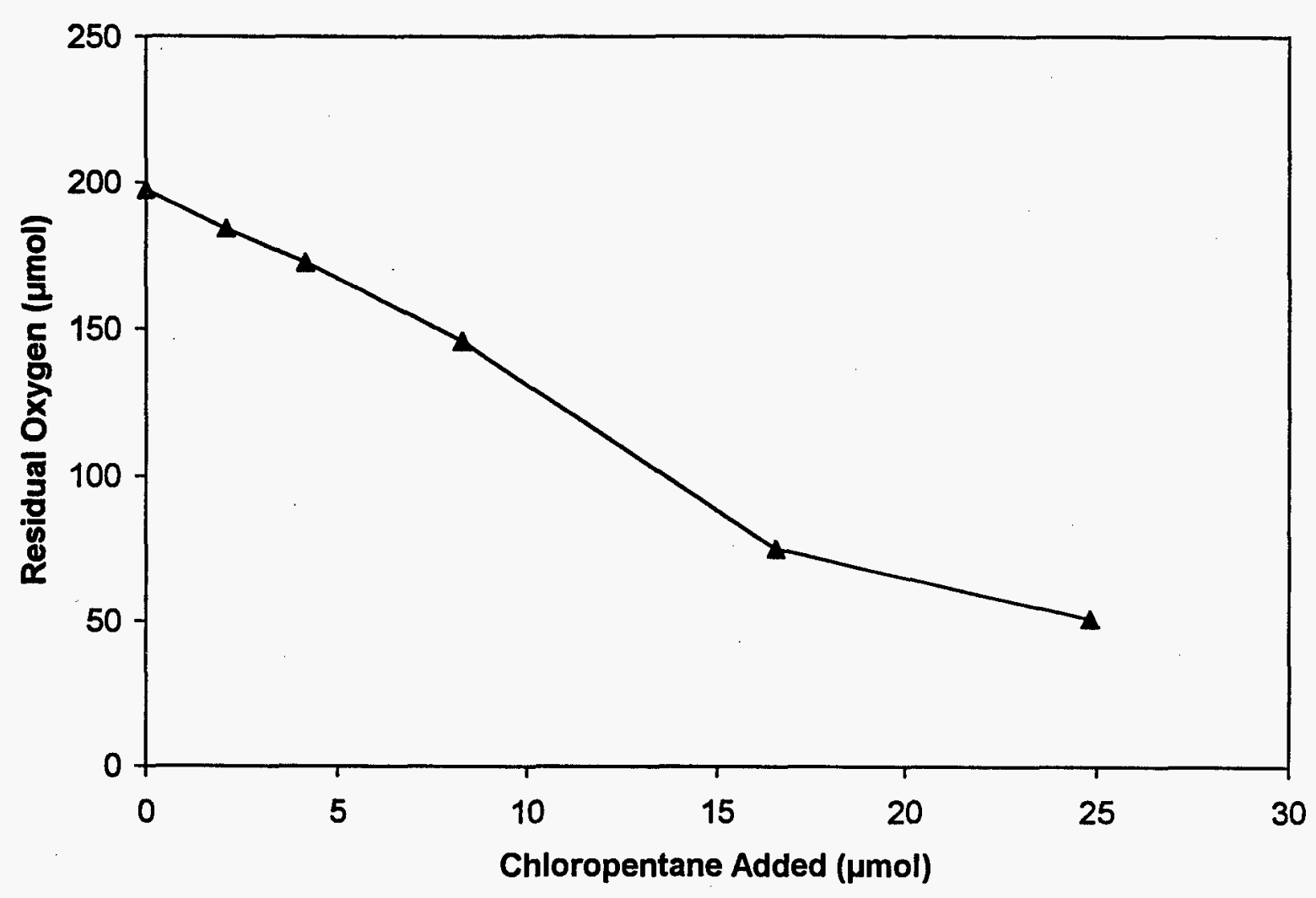


Figure 7. VOC removal efficiency in a continuous flow trickle bed reactor for various temperatures.

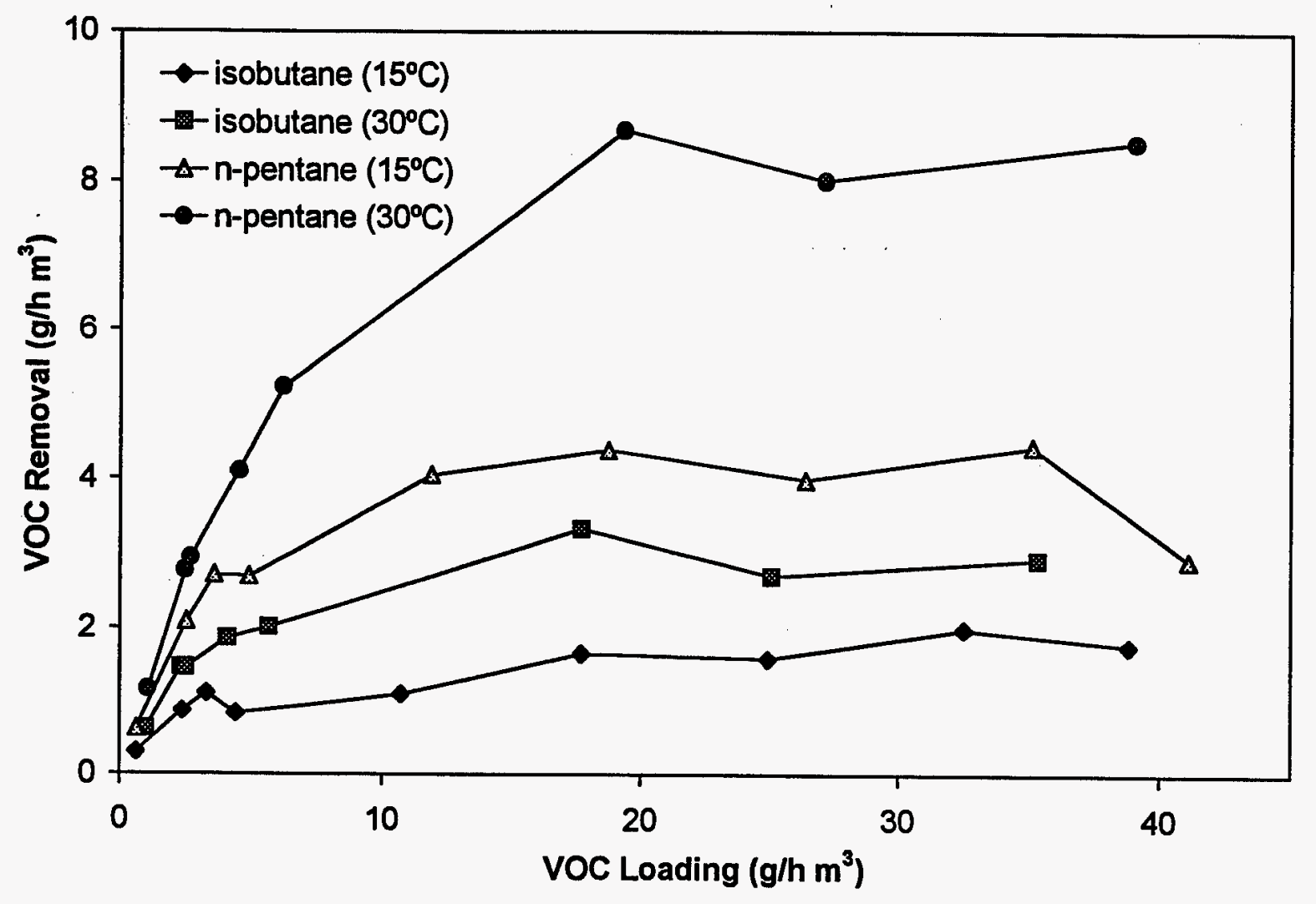


M98004265

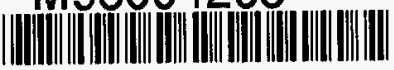

Report Number (14) ORNL/CP--96394

Publ. Date (11) 199801

Sponsor code (18) DOE/EM, XF

UC Category (19) UC-2000, DOE/ER

DOE 